\title{
Catch Composition and Selectivity of Fishing Gears in a Multi-Species Indonesian Coral Reef Fishery
}

\author{
Austin T. Humphries ${ }^{1,2 *}$, Kelvin D. Gorospe', Paul G. Carvalho', Irfan Yulianto ${ }^{3,4}$, \\ Tasrif Kartawijaya $^{3}$ and Stuart J. Campbell ${ }^{5}$ \\ ${ }^{1}$ Department of Fisheries, Animal and Veterinary Science, The University of Rhode Island, Kingston, RI, United States, \\ ${ }^{2}$ Graduate School of Oceanography, University of Rhode Island, Narragansett, RI, United States, ${ }^{3}$ Marine Programs, Wildlife \\ Conservation Society, Bogor, Indonesia, ${ }^{4}$ Faculty of Fisheries and Marine Sciences, Bogor Agricultural University, Bogor, \\ Indonesia, ${ }^{5}$ Rare Indonesia, Bogor, Indonesia
}

\section{OPEN ACCESS}

Edited by:

Tomaso Fortibuoni,

Higher Institute for Environmental Protection and Research (ISPRA), Italy

Reviewed by: Ruth H. Thurstan, University of Exeter, United Kingdom Tommaso Russo

University of Rome Tor Vergata, Italy

${ }^{*}$ Correspondence: Austin T. Humphries humphries@uri.edu

Specialty section: This article was submitted to Marine Fisheries, Aquaculture and Living Resources, a section of the journal Frontiers in Marine Science

Received: 13 February 2019 Accepted: 18 June 2019

Published: 04 July 2019

Citation:

Humphries AT, Gorospe KD, Carvalho PG, Yulianto I, Kartawijaya T

and Campbell SJ (2019) Catch Composition and Selectivity of Fishing Gears in a Multi-Species Indonesian Coral Reef Fishery.

Front. Mar. Sci. 6:378. doi: 10.3389/fmars.2019.00378
There are millions of small-scale fishers worldwide that rely on coral reefs for their livelihood. Yields from many of these coral reef fisheries, however, have been declining. In Indonesia and other coral reefs worldwide, management approaches are dominated by marine protected areas but other options including gear-restrictions may be feasible and more adaptive to local ecological and social conditions. Yet, there is little data on the impacts and selectivity of fishing gears for coral reef fisheries. In this paper, we present results from a case study on the island of Lombok, where we examine the selectivity and overlap in catch composition of the two main fishing gear types: spearguns and handlines. The catch per unit effort (CPUE) was greater in handlines than spearguns, 10.8 and $9.97 \mathrm{~kg} \mathrm{trip}^{-1}$, respectively. The two gears targeted different fish communities with little overlap in dominant species, suggesting a partitioning of resources; handlines targeted piscivores, whereas spearguns targeted mostly herbivores. Mean trophic level was 3.6 for the handline catch and 2.8 for spearguns, where it was inversely related to CPUE. Spearguns captured more species overall and the number of species increased as the CPUE increased. Length parameters of maturity indicated that neither gear showed signs of (growth) overfishing and fishing grounds dominated by speargun fishers had catches associated with younger ages at first maturity than handlines. Our findings provide local baseline data on the potential utility of gear restrictions as a management tool. Specifically, managers could monitor reefs and reduce handlines when piscivorous fishes are low and on spearguns when species diversity is low or algal abundance is high. Should it become more desirable to implement ecosystem approaches to management that are adaptive to changing ecological and social conditions, these indicators may be used as starting points along with local management preferences of fishers.

Keywords: adaptive management, fisheries evaluation, Indonesia, catch per unit effort, data-poor fisheries

\section{INTRODUCTION}

Indonesia has the second longest coastline and the greatest coral reef area of any country in the world (Spalding et al., 2001). Yet, many of Indonesia's coral reefs are declining from a variety of anthropogenic stressors (Chou et al., 2002). These habitat changes, coupled with overfishing, negatively impact the 1.7 million coral reef fishers in Indonesia (Teh et al., 2013). The coral reef 
fisheries of Indonesia are small-scale and scattered, with a de-centralized management scheme across the 17,000-island archipelago. The management paradigm thus far has been to create marine protected areas (MPAs) even though the practical difficulty in establishing them is high. In fact, it is estimated that 216 MPAs have been established across Indonesia, covering approximately 3\% of their territorial waters (Marine Conservation Institute, 2019). The ability of MPAs to impact not just biodiversity but also fisheries, however, has been shown to be largely dependent on not only fish dispersal and ecological interactions (Walters, 2000), but also the ability of the government to enforce restrictions (Gill et al., 2017). When enforcement does not take place, poaching occurs and MPAs are ineffective (Mangubhai et al., 2011), as is often the case in the island archipelago of Indonesia. Consequently, considering other management options for coral reefs would give managers more tools to enable and facilitate sustainable fisheries.

The coral reef fishers in Indonesia use multiple gear types to capture a variety of fish species (Pet-Soede et al., 2001; Campbell et al., 2014). Gillnets, beach seines, handlines, spearguns, and traps are used and often together at the same time. Blast fishing with dynamite and cyanide poison is also used for both food fish as well as the aquarium trade (Halim, 2002). Destructive fishing gears in Indonesia harm reefs at an estimated opportunity cost of more than USD $\$ 300,000$ per $\mathrm{km}^{2}$ of coral (Pet-Soede et al., 1999). In some areas, there are customary marine tenure rights that are recognized by the Indonesian government. These commonly exist as periodically harvested closures called sasi (Harkes and Novaczek, 2002) or gear restrictions enforced by the local tribal leader called Panglima Laot (Campbell et al., 2012). In this case, study on the island of Lombok, Indonesia, the dominant gears are spearguns and handlines. There are some customary practices in place that include both sasi and Panglima Laot. Historical mismanagement of fishing gears and associated effort, however, has led to sentiments of declining catches with increasing effort.

In many areas, fishing communities have more willingness to comply with gear restrictions than other management options (McClanahan and Abunge, 2018). Gear-based management is a potential option for coral reef fisheries in Indonesia and on the island of Lombok because it is adaptable to the local ecological and social conditions, including customary practices. Restricting gears can also be a low-cost method to manage wide ranging and dispersed multi-species fisheries and result in biomass gains relative to openly fished areas (Campbell et al., 2018). Yet there are few studies on gear selectivity for coral reef fisheries in Indonesia (but see Campbell et al., 2014), and none that examine fish at the species-level (Pet-Soede et al., 2001; Campbell and Pardede, 2006). There are data on gear selectivity, however, from other coral reef systems such as Kenya (McClanahan and Mangi, 2004; Hicks and McClanahan, 2012), the Seychelles (Daw et al., 2011), Papua New Guinea (McClanahan and Cinner, 2008), the Philippines (Maypa et al., 2002), and Puerto Rico (Acosta, 1994). Fishing gears in these areas have all been found to be selective to some degree, either by size, species or functional role, or a combination of these attributes, making them feasible management options. An understanding of the impact of different fishing gears on Indonesian coral reefs would allow for locally informed management strategies to be developed that can act as a compliment to existing management strategies, both customary and government regulated.

In this study, we analyze catches from coral reef fishers on the island of Lombok, Indonesia. Located in the Lesser Sunda Seascape, Lombok has one of the highest levels of reef fish endemism in the Coral Triangle (Allen, 2008). Along with agriculture, fishing is the primary form of livelihood making it vital to well-being. These fisheries are quasi managed with customary practices and MPAs intermixed in an attempt to increase tourism. In the area of this study, southwest Lombok, enforcement of these MPAs is carried out by individuals in local community organizations (termed "pokmaswas"). Data is largely non-existent on the success of these management strategies for fish and fisheries. Fishers and other stakeholders in Lombok, however, have expressed interest in actively managing the fisheries to increase productivity. In particular, how fishing with one gear over another might be more beneficial to them and the reef. It is within this context that we assessed the catch composition and selectivity of the two dominant gear types used in the coral reef fishery - spearguns and handlines. We were interested in understanding the catches of each gear, how they compare with one another, and what gear restrictions might be feasible as an adaptive management strategy.

\section{MATERIALS AND METHODS}

\section{Data Collection}

This study was conducted in the southwest part of Lombok Island, Sekotong sub-district, from September 2014 to December 2015 (Figure 1). More than 29,000 inhabitants from approximately 8,000 households live in this area and more than $50 \%$ of the households are dependent on fishing for their income and food. Here, fishers catch reef fish in shallow coral reef areas. Fishers typically sell the fish to home stays, local resorts, and at local markets. The data collected represents all fish caught in the Sekotong sub-district on coral reefs except for approximately 5\% that was used for direct household consumption. In this fishery, there are no discards or high-grading, as all fish caught are either sold or consumed.

To collect data, we monitored fish landings across four sites: Teluk Sepi, Batu Putih, Tembowong, and Batu Kijuk (Figure 1). At each landing site, enumerators opportunistically examined fish at all times of the day and night. Enumerators asked permission from fishers if they could examine their catch as they returned from fishing. If more than one fisher or boat was returning at the same time, enumerators randomly selected who to approach. Enumerators then recorded the total length $(\mathrm{cm})$ of each fish caught and identified the species of each fish. Enumerators were trained on fish identification by expert fishery scientists on the common coral reef species before going to the field. If the species was not known, enumerators took a photograph of the specimen and confirmed identification with a taxonomist so as to reduce error in identification. Additionally, the enumerators asked fishers where they caught the fish, i.e., the fishing ground, as well as the fishing gear used. If fishers could 


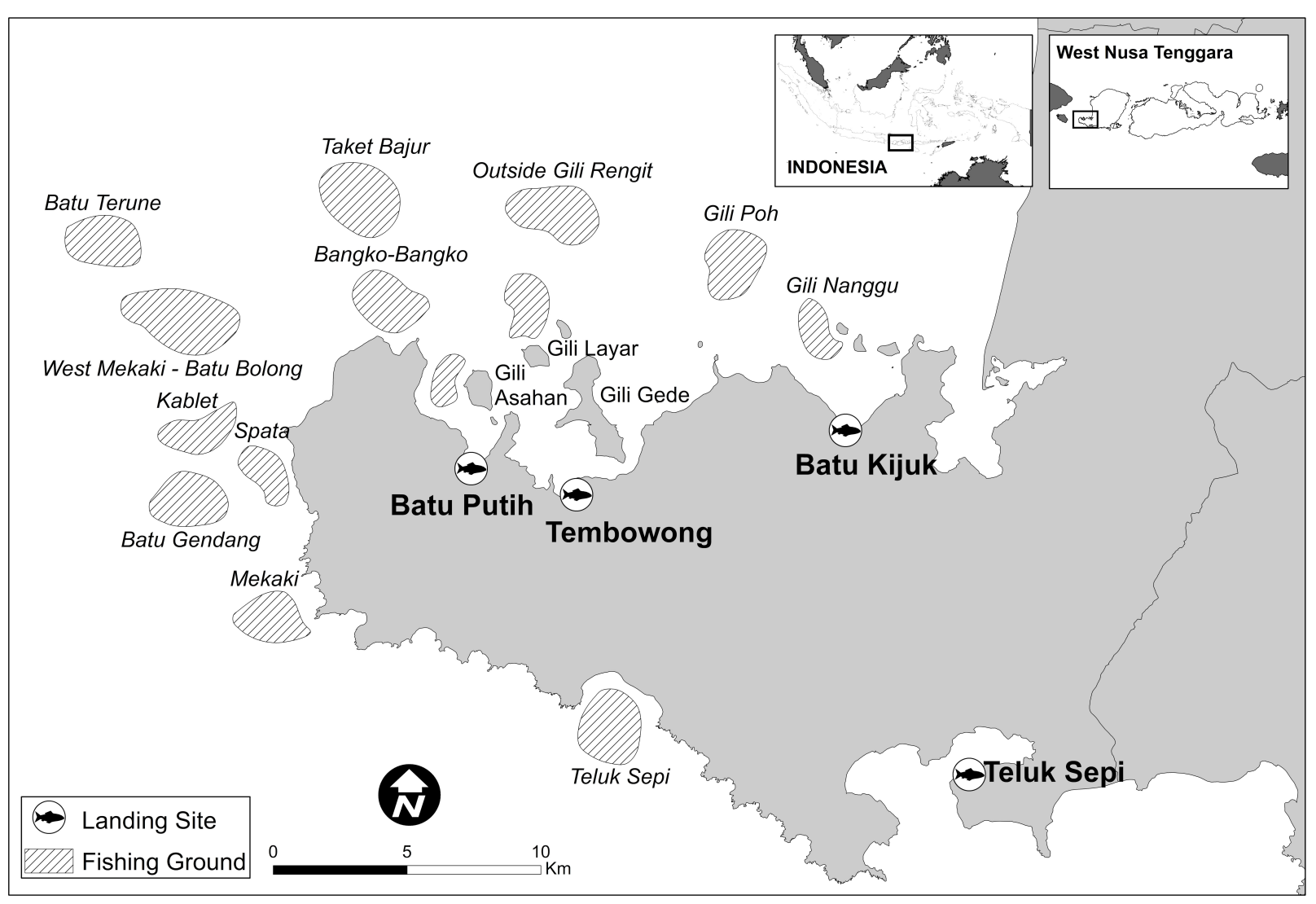

FIGURE 1 | Fishing ground locations and landing sites where data was collected in the Sekotong region of Lombok, Indonesia.

not identify the fishing ground by pointing to it on a map or the gear they used, their catches were not recorded $(<3 \%$ of the data). If multiple gears were used in a trip, the fish were separated according to gear type. Data were collected every month during the 16-month study duration.

Fishers targeting coral reef fishes in this area of Lombok Island usually go out on a trip for 6-8 h and rarely if ever do they stay out fishing for more than $12 \mathrm{~h}$ (A. Humphries personal observation). The most common gears used in this coral reef fishery are the speargun and hand line. Typical spearguns here have a wooden stock of approximately $30 \mathrm{~cm}$ in length, where a sharpened steel rod (spear) is loaded with a bungee release system. The spear is attached to the wooden handle with string. Fishers using spearguns typically spend $4-6 \mathrm{~h}$ in the water fishing per trip and fish at depths between 3 and $10 \mathrm{~m}$. Handlines are monofilament lines wrapped around a spool with anywhere from one to approximately 20 hooks attached at regular intervals, using either bait on the hook or colored strings attached to the hook shank. Most common (>90\%), however, are handlines with one hook using bait and are used for $4-6$ h per trip and fished at a depth of 5-15 m.

\section{Data Analysis}

We define selectivity in the context of this study and fishing gears as the proportion of fish caught by each fishing gear type (McClanahan and Cinner, 2008). We used one fishing trip as our standard unit of effort and calculated total fish biomass (kg) per trip to represent catch per unit effort (CPUE). CPUE was log-transformed to create a normal distribution for subsequent analyses. To compare the effects of fishing effort on total and functional-level diversity, we calculated total species richness and mean trophic level (as reported in FishBase; Froese and Pauly, 2018) per fishing trip. For the latter, each species' trophic level was weighted by their proportional biomass within each trip (McClanahan and Humphries, 2012). To compare gear types in terms of their overall catch, we used one-sided $t$-tests to compare mean CPUE and mean trophic level, then calculated a Bray-Curtis dissimilarity index between the two gear types. We then used linear regression to predict both species richness and mean trophic level for different levels of CPUE.

In order to determine whether (growth) overfishing was occurring in these fisheries, we calculated and compared the biomass-weighted length at maturity $\left(\mathrm{L}_{\text {mat }}\right)$ to the sizefrequency distributions of each gear type's total catch (Hicks and McClanahan, 2012). This allowed us to assess whether the growth potential was being fully utilized in the fishery. We then used a two sample Kolmogorov-Smirnov test to determine whether the length-frequency distributions of each gear type were significantly different from one another. 
To explore relationships between fishing ground, gear, and catch composition with life-history characteristics we performed a redundancy analysis (RDA; Oksanen et al., 2017). Redundancy analysis is a constrained ordination method that is meant to display the variation of a data matrix which is best explained by a linear combination of explanatory variables. For this analysis, life-history characteristics were used as explanatory variables of species abundance for each combination of fishing ground and gear type. We compiled data on eight life-history parameters from FishBase (Froese and Pauly, 2018), including: intrinsic growth rate, life span, generation time, natural mortality rate, age at first maturity, maximum length, length at maturity, and length to achieve optimum yield. If there were no data for a species, we used the most closely related species values. We calculated weighted life-history parameters using proportional biomass per fishing trip following McClanahan and Humphries (2012). We then used a Pearson correlation test to determine which of the weighted life-history parameters to include in the RDA. Those parameters that had absolute values greater than 0.5 were not included.

\section{RESULTS}

A total of 6994 individual fish were sampled across 192 unique species (Table 1). Specifically, 3683 individuals across 98 species were caught by handline, and 3311 individuals across 159 species were caught by speargun. The total dataset was used to compare catch composition and the relationship between CPUE with species richness and mean trophic level (Table 1). We only used the top 20 species caught by each gear type for plotting sizefrequency distributions so as to remove the influence of outliers. Finally, fishing grounds with fewer than 30 individual fish per gear type were removed, resulting in a total of 4458 individual fish for the RDA. These fish were landed across six fishing grounds. The fishing grounds with the most abundant catches - Gili Asahan followed by Mekaki and Bangko-Bangko (Table 2) - had both gear types in use on the same coral reef habitat assemblage. The remaining fishing grounds (Gili Nanggu, Batu Terune, and Gili Layar) had catches with only one gear being used.

The top 20 species comprised more than $70 \%$ of the total catch by abundance, and the top species caught in this fishery was Acanthurus mata (Figure 2). While most of the top 20 species were caught by both gears, Etelis coruscans, Gymnocranius microdon, Lutjanus timoriensis, and Nemipterus furcosus were

TABLE 1 | Sample sizes (number of individual fish) used for each analysis.

\begin{tabular}{ll}
\hline Total number of fish & Analysis \\
\hline 6994 & $\begin{array}{l}\text { Catch composition (Bray-Curtis similarity and } t \text {-tests) } \\
\text { Relationship between catch per unit effort with species } \\
\text { richness and mean trophic level (linear regression) } \\
\end{array}$ \\
$\begin{array}{l}\text { Size-frequency distributions (Kolmogorov-Smirnov test) } \\
4458\end{array}$ & Life-history characteristics (redundancy analysis) \\
\hline $\begin{array}{l}\text { The numbers differ according to the analysis because of outliers and species with } \\
\text { very few individuals. }\end{array}$
\end{tabular}

TABLE 2 | Fishing ground, gear type, and number of individual fish landed and used in the redundancy analysis (RDA).

\begin{tabular}{lllc}
\hline RDA label & Fishing ground & Gear type & Fish landed \\
\hline 1 & Bangko-Bangko & Handline & 961 \\
2 & Gili Asahan & Handline & 81 \\
3 & Gili Nanggu & Handline & 149 \\
4 & Mekaki & Handline & 1071 \\
5 & Bangko-Bangko & Speargun & 172 \\
6 & Batu Terune & Speargun & 46 \\
7 & Gili Asahan & Speargun & 1495 \\
8 & Gili Layar & Speargun & 329 \\
9 & Mekaki & Speargun & 154 \\
\hline
\end{tabular}

exclusively caught by handline, while Scarus xanthopleura was exclusively caught by speargun. Speargun also caught most of the herbivorous species such as Acanthurus mata, Naso brevirostris, Naso caeruleacauda, Naso literatus, Naso unicornis, and Naso vlamingii, and Scarus xanthopleura.

Mean CPUE for spearguns was $9.97 \mathrm{~kg} \operatorname{trip}^{-1}( \pm 0.12)$ and $10.8 \mathrm{~kg} \mathrm{trip}^{-1}( \pm 0.16)$ for handlines. Mean trophic level followed a similar pattern, where spearguns had a lower value of $2.8( \pm 0.05)$ than handlines which was $3.6( \pm 0.07)$. Onesided $t$-tests showed that speargun catch was significantly lower than handline catch for both mean CPUE $(t=-4.0151$, $d f=128.31, p<0.001)$ and mean trophic level $(t=-9.476$, $d f=131.51, p<0.001)$. The Bray-Curtis dissimilarity index between the total fish communities caught by speargun vs. handline was 0.68 , indicating that they share few species in common. Linear models for species richness (Figure 3A) were found to be significant ( $p<0.001$ ) for both gear types, however, the fit was much greater for handline $\left(R^{2}=0.54\right)$ vs. speargun $\left(R^{2}=0.16\right)$. In contrast to species richness, however, CPUE was a significant predictor of mean trophic level only for speargun fishing trips (Figure 3B; $p<0.05 ; R^{2}=0.08$ ). This dataset consisted of 63 spearfishing trips and 72 handline trips (16 trips contained a mixture of gears and were dropped for trip-level analyses).

Handline catches had a wider range of fish sizes than spearguns and the two sample Kolmogorov-Smirnov test indicated they were significantly different from one another ( $D=0.349, p<0.001$; Figure 4). The sizes of handline catches ranged from 10 to over $100 \mathrm{~cm}$, whereas spearguns caught fish between 15 and $80 \mathrm{~cm}$ and over $70 \%$ was between 20 and $40 \mathrm{~cm}$. Comparing the size-frequency distributions to mean length at first maturity, we found that $58.6 \%$ of the catch was above length at first maturity for handlines, which was $31 \mathrm{~cm}$. For spearguns, this number was greater and $69.3 \%$ of the catch was mature or above an $\mathrm{L}_{\text {mat }}$ of $25 \mathrm{~cm}$.

There were several significant correlations among the lifehistory parameters and 3 groups emerged using a Pearson's $r$-value of greater than 0.5: (1) maximum length was correlated with length at maturity and length to achieve optimum yield; (2) natural mortality rate was correlated with length at maturity, length to achieve optimum yield, and intrinsic rate of growth; and (3) mean trophic level was correlated with mean life span, 


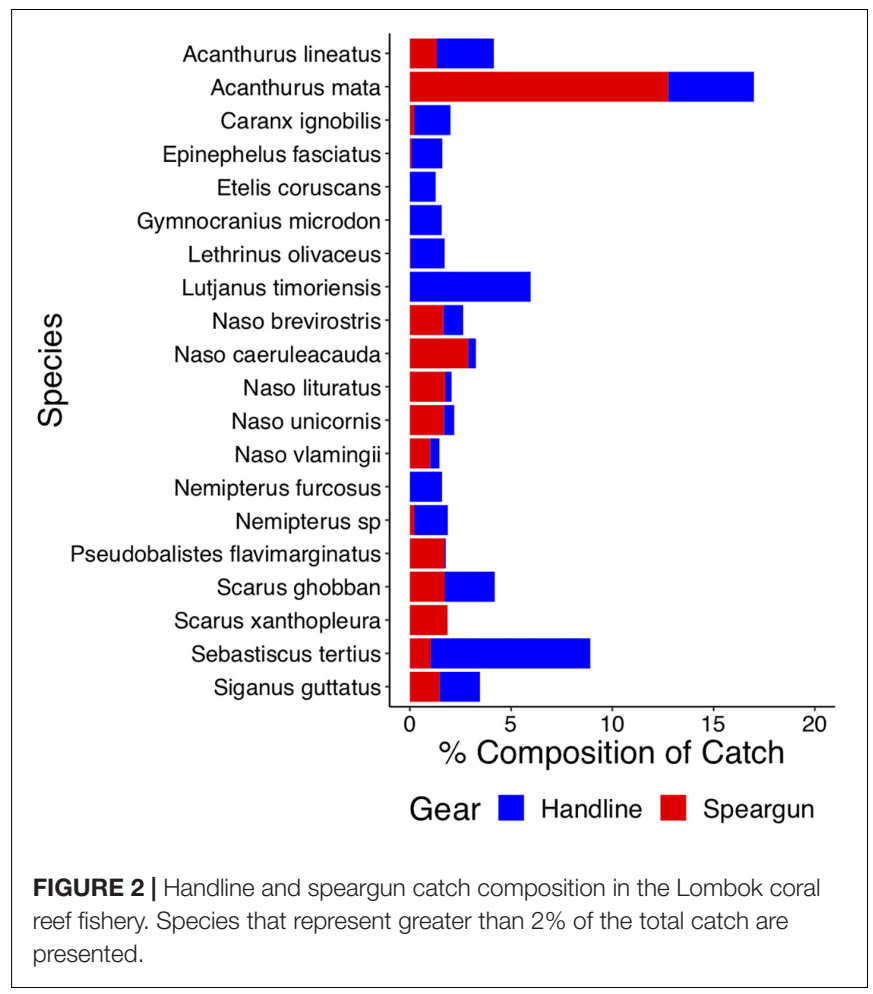

mean generation time, and time to maturity. Thus, we retained maximum length $\left(\mathrm{L}_{\max }\right)$, natural rate of mortality, and age at first maturity (tm) to remove all significant collinearity. A total of nine fishing ground and gear type combinations were used in the RDA as unique observations (Table 2). Ordination of fish catches by their weighted life-history characteristics showed that gear types were successfully represented in RDA space $(F=1.94, p<0.01$; Figure 5$)$. RDA axis 1 explained $22.4 \%$ of the variation and separated sites based primarily on their age at first maturity; sites one and four that were associated with older ages at first maturity were represented by negative RDA1 values, whereas those with younger ages at first maturity had positive values. RDA axis 2 explained $17.4 \%$ of the variation and represented a gradient of fish catches composed of species with high natural mortality rates (positive RDA2 values), vs. those with high maximum lengths (negative RDA2 values).

\section{DISCUSSION}

This study shows differences in the fish communities being targeted by spearguns and handlines, the two primary gears used in the multi-species coral reef fishery of Lombok, Indonesia. There was low overlap and competition between these gears, suggesting a partitioning of resources (i.e., fish). Handlines targeted more fish that were under length at first maturity, and primarily higher trophic level piscivorous species. Both gears caught a high diversity of fish, but spearguns removed more species and these were dominated by herbivorous fishes. The majority of the fishing grounds

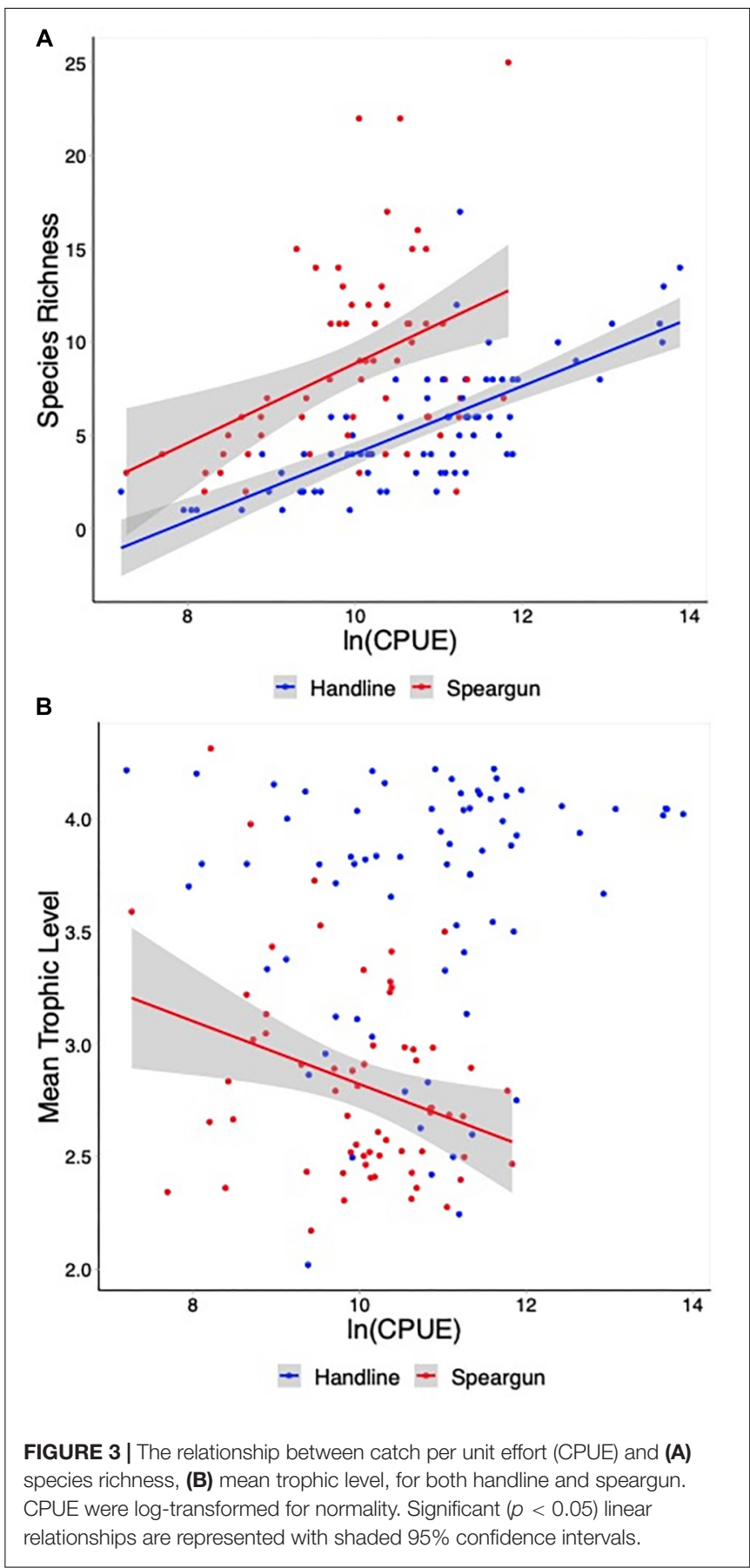

in this area were fished with both gear types. Some of these fishing grounds were associated with catches that had species with greater maximum lengths, whereas others had catches representing greater natural mortality rates and older ages at first maturity. Synthesizing these results with current understandings of ecosystem functioning and local fishing preferences will enable adaptive management of these coral reefs using gear restrictions.

While there was a high diversity of species caught, each gear was selective and dominated by a few species that occupied 


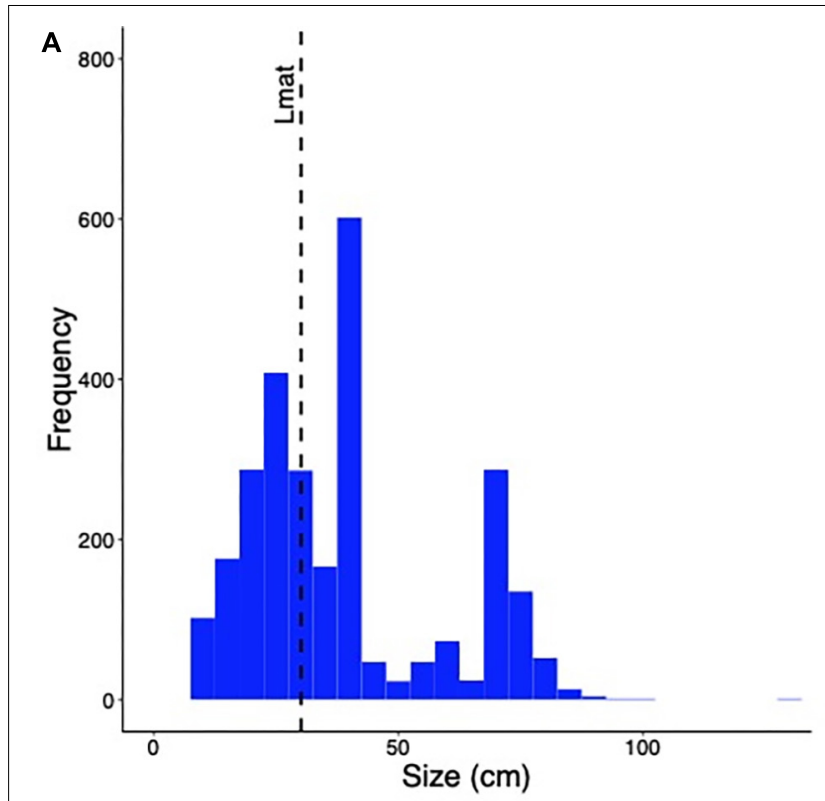

B

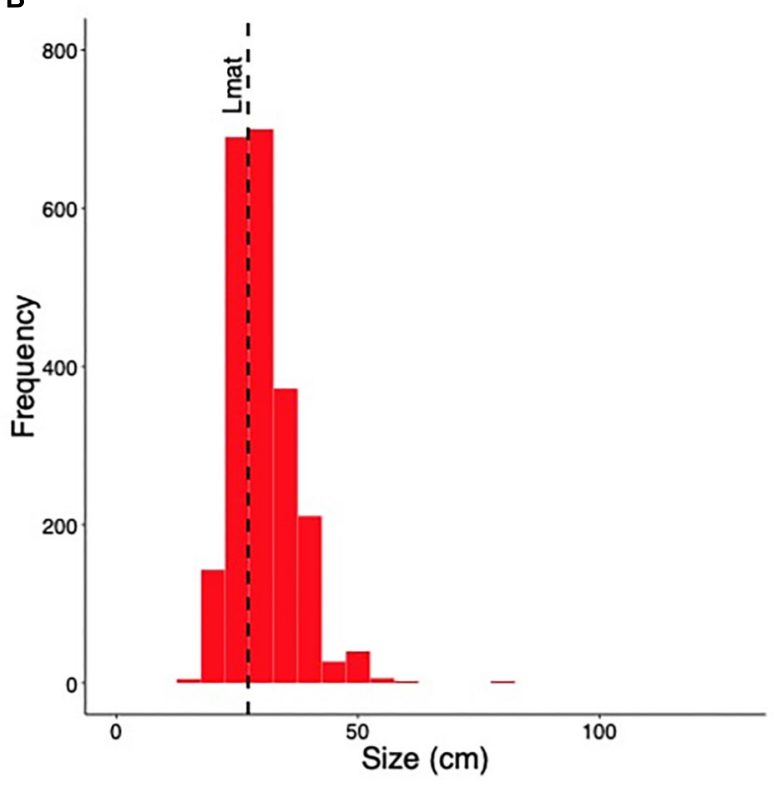

FIGURE 4 | Size-frequency distribution of fish captured using (A) handline, and (B) speargun. The dashed line represents the biomass-weighted mean length $(\mathrm{cm})$ at first maturity of the catch $\left(L_{\text {mat }}\right)$.

different functional roles. Speargun catches were dominated by Acanthurus mata, an herbivorous surgeonfish. The other species in speargun catches were also mostly herbivores, either unicornfish or parrotfish. Since many of the speargun fishers in this area of Lombok (and globally) go out during the nighttime, it is not surprising that these species dominate the catch. Parrotfish, for example, have been shown to scatter throughout the reef during the daytime but aggregate on reef platforms during the evening (Hobson, 1972; Ogden and Buckman, 1973). Reductions in herbivores can lead to low

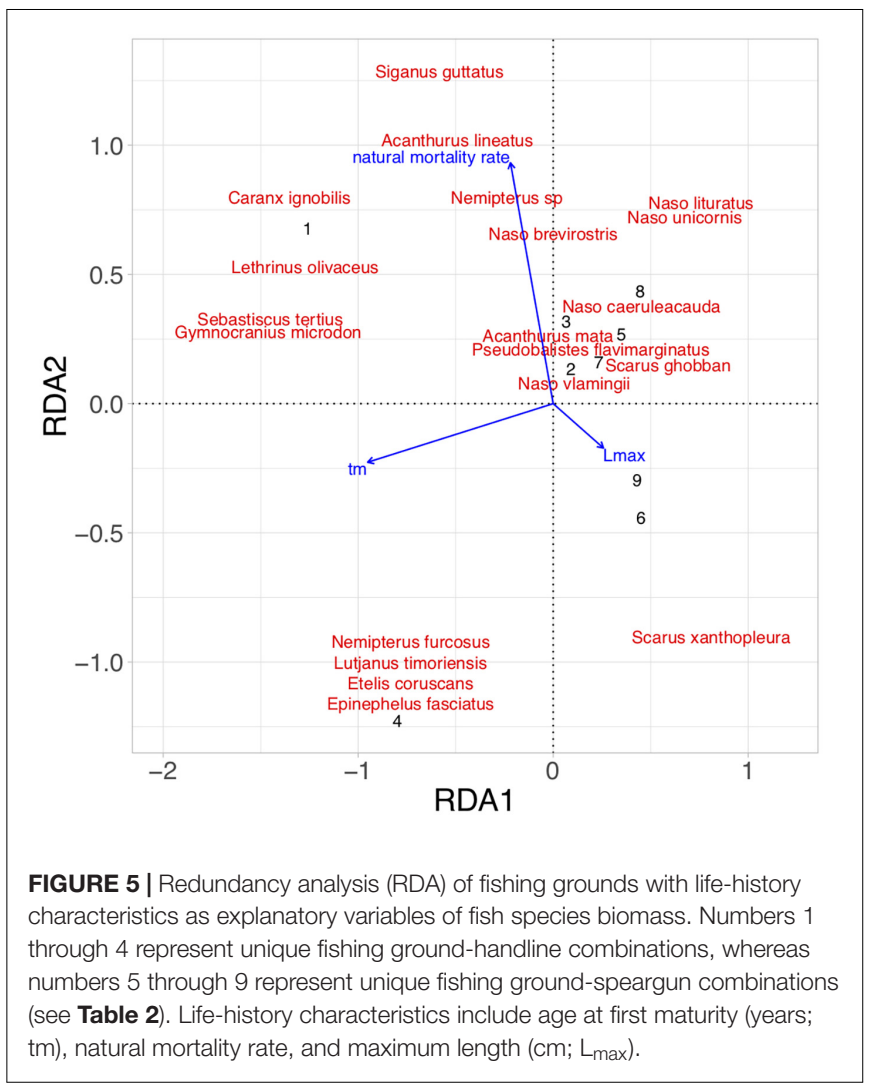

herbivory rates (Kelly et al., 2017) and allow certain macroalgae to proliferate (Humphries et al., 2015), which may or may not reduce the resilience of reefs to global stressors (Bruno et al., 2019). Macroalgae in this area of Lombok, however, is not a major concern of fishers or managers but could be in the future should herbivores be overfished. Spearguns in other coral reef fisheries such as Papua New Guinea (McClanahan and Cinner, 2008) and Kenya (McClanahan and Mangi, 2004) showed similar results in catch composition, but the size of herbivores in this study were much larger (as was the CPUE).

Species diversity is an important ecosystem metric that has been shown to reflect fishing pressure and impacts on systemlevel resilience (Watson et al., 1996; McClanahan et al., 2011). We found spearguns to remove more species from the reef than handlines and that this increases as CPUE increases. This relationship showed no signs of leveling off or reaching a saturation point where more catch came at little to no cost to species richness (e.g., McClanahan and Cinner, 2008). A few explanations are possible, one being that the coral reefs in this area have not been overfished and thus diversity remains high (Yachi and Loreau, 1999). The fact that the majority of the catch from spearguns is above length at first maturity supports this hypothesis, but without historical data or previous assessments of fish and fishery status, this is difficult to say for certain. Another factor could be that environmental effects are overriding fishing effects in determining fish community structure on these reefs, allowing for very high coral and fish 
diversity (Allen, 2008). For instance, the Bali Strait is nearby the fishing grounds in this study and it has seasonal upwellings which delivers zooplankton to the reef habitat (Ningsih et al., 2013). Zones such as this have been shown to facilitate increased species diversity in Indonesia and worldwide (Irigoien et al., 2004; Gaither and Rocha, 2013).

Applying an ecosystem approach to fisheries management is considered the preferred option and best practice by the Indonesian Ministry of Marine Affairs and Fisheries for the long-term sustainability of fisheries and the ecosystem services provided to society (e.g., food security, livelihoods, economic security, coastal protection, human health, and well-being; Muawanah et al., 2018). The maintenance of a constant mean trophic level of fisheries catch is one goal of an ecosystem approach to fisheries management. This is intended to be one way to maintain functional diversity within a fishery and ecosystem (Gascuel, 2005). This can be achieved by monitoring catch and adjusting the gear portfolio accordingly so that mean trophic level does not decline (Pauly et al., 1998). We examined this in Lombok by comparing the mean trophic level with CPUE and found no relationship for handlines. In other words, the handline fishers caught a wider variety of fish species that spanned different trophic levels and functional groups regardless of their harvest efficiency. In fact, handline catches tended to target higher trophic level species in the snapper, emperor, and grouper families. These included the rockfish Sebastiscus tertius and snapper species such as Lutjanus timoriensis, both generalized predators that occupy a wide variety of habitats, not just coral reefs (Allen and Erdmann, 2012). Handline catches in the Karimunjawa Islands, Indonesia, had similar species compositions and the mean trophic level was also close to 4.0 (Campbell et al., 2014). This is in contrast to spearguns, where we found a negative relationship between mean trophic level and CPUE.

Fish life-history characteristics are an important component of fisheries assessments and they also represent an important means of grouping species in terms of their ability to cope with fishing mortality and other environmental stressors (Winemiller and Rose, 1992). As such, species with similar life-history traits may also benefit from similar management frameworks. For example, for opportunistic species with early maturation and shorter generation times, management that focuses on maintaining a minimum level of spawning stock biomass will be essential (King and McFarlane, 2003). Because speciessingle assessments are impractical for coral reef fisheries, where many species are caught with one gear, we used biomass-weighted mean life-history characteristics as indices (McClanahan and Graham, 2015). Comparison of the mean length at first maturity with the length-frequency distribution of Lombok's fish catch composition indicated that there was little loss of fisheries yield due to overexploitation of smaller fish that have not yet reached reproductive maturity. On the other hand, RDA revealed that the catch composition of spearguns was more selective than handlines in terms of life history characteristics. Specifically, the speargun fishery was largely composed of species that had low ages at first maturity (i.e., opportunistic strategists; Taylor et al., 2014). In contrast, the handline fishery was less consistent in terms of the life-history characteristics of its catch, targeting species with both low and high natural mortality rates and ages at first maturity.

Both gear types in this study are likely to vary in their selectivity depending on when they are used, experience of the fisher, and what habitats they target such as the reef crest or slope (Diogo et al., 2017). Unfortunately, we were not able to capture these variables in our analysis as is often the case with data-poor fisheries. The dynamics of this particular fishery in Lombok, however, is that the speargun and handline fishers are fishing on the same coral reefs (i.e., overlap in fishing grounds) and at relatively similar depths (3-15 m). This controls for major differences in catch composition and gear selectivity attributable to habitat or environmental effects. One limitation of our study in the context of management was the inability to identify thresholds or specific tipping points with regards to when gear regulations could be implemented (Hughes et al., 2010). This is largely because we had no previous data on the status of fish and fisheries in Lombok, and because we had no time series data. This study sets a benchmark for fisheries catch in Lombok and can be used to evaluate the efficacy of future management policies. Continued monitoring of catch composition will allow for such an evaluation and of the effects of different gears through time, thus providing indicators that inform adaptive management (Walters, 1986). Furthermore, testing the efficacy of gear restrictions with field studies will be important as well (e.g., Johnson, 2010; Gomes et al., 2014). Finally, there is a need to pair fish landings data with fisheries-independent ecological data such as underwater visual census of reef fish communities and benthic cover and condition (Daw et al., 2011; Nash et al., 2016). Only then can an adaptive ecosystem approach to fisheries management be effectively implemented in Lombok an across Indonesia and the effects of fisheries on coral reef ecosystems be understood.

Adapting to changing environmental and social conditions is a primary yet elusive goal for fisheries management globally and in Indonesia. In this case, study on Lombok, we focused on evaluating species and functional diversity as well as community-level life history characteristics of fish catch composition for different fishing gears. The findings provide data for the potential utility of gear restrictions as a tool for managing the local multi-species fishery. If gear restrictions were desirable, managers could monitor reefs and/or catches and when piscivorous fishes are depleted, or the mean trophic level of catches is decreasing, they could reduce the use of handlines. Alternatively, when algal abundance is high or species diversity on reefs is low, a restriction on spearguns should increase herbivore abundance and species richness. Gear restrictions in this context will be most effective when established with fisher input and participation (Heyman and Granados-Dieseldorff, 2012). The preferences of fishers toward gear restrictions should be further investigated before implementing policy as cultural beliefs and traditions may prevent or facilitate the process. 


\section{DATA AVAILABILITY}

The datasets generated for this study are available on request to the corresponding author.

\section{ETHICS STATEMENT}

No ethical clearance or approval was needed for this study because human subjects were not involved, nor were animal subjects utilized other than counting what had already been captured by fishers. No clinical trials were performed.

\section{AUTHOR CONTRIBUTIONS}

$\mathrm{AH}, \mathrm{KG}$, and $\mathrm{PC}$ conceived the original ideas and analyzed the data. AH, IY, TK, and SC funded the study and collected the data. $\mathrm{AH}$ and $\mathrm{KG}$ wrote the first draft of the manuscript. All authors contributed substantially to revisions.

\section{REFERENCES}

Acosta, A. R. (1994). Soak time and net length effects on catch rate of entangling nets in coral reef areas. Fish. Res. 19, 105-119. doi: 10.1016/0165-7836(94) 90017-5

Allen, G. R. (2008). Conservation hotspots of biodiversity and endemism for Indo-Pacific coral reef fishes. Aquat. Conserv. 18, 541-556. doi: 10.1002/aqc.880

Allen, G. R., and Erdmann, M. V. (2012). Reef Fishes of The East Indies. Volumes I-III. Perth: Tropical Reef Research.

Bruno, J. F., Côté, I. M., and Toth, L. T. (2019). Climate change, coral loss, and the curious case of the parrotfish paradigm: why don't marine protected areas improve reef resilience? Annu. Rev. Mar. Sci. 11, 307-334. doi: 10.1146/ annurev-marine-010318-095300

Campbell, S. J., Cinner, J. E., Ardiwijaya, R. L., Pardede, S., Kartawijaya, T., Mukmunin, A., et al. (2012). Avoiding conflicts and protecting coral reefs: customary management benefits marine habitats and fish biomass. Oryx 46, 486-494. doi: 10.1017/s0030605312000348

Campbell, S. J., Edgar, G. J., Stuart-Smith, R. D., Soler, G., and Bates, A. E. (2018). Fishing-gear restrictions and biomass gains for coral reef fishes in marine protected areas. Conserv. Biol. 32, 401-410. doi: 10.1111/cobi. 12996

Campbell, S. J., Mukminin, A., Kartawijaya, T., Huchery, C., and Cinner, J. E. (2014). Changes in a coral reef fishery along a gradient of fishing pressure in an Indonesian marine protected area. Aquat. Conserv. 24, 92-103. doi: 10.1002/aqc.2359

Campbell, S. J., and Pardede, S. T. (2006). Reef fish structure and cascading effects in response to artisanal fishing pressure. Fish. Res. 79, 75-83. doi: 10.1016/j. fishres.2005.12.015

Chou, L. M., Tuan, V. S., Philreefs, Y. T., Cabanban, A., and Suharsono, K. I. (2002). "Status of Southeast Asia coral reefs," in Status of Coral Reefs of The World, ed. C. Wilkinson (Townsville, QLD: Australian Institute of Marine Science), 123-153.

Daw, T. M., Robinson, J. A. N., and Graham, N. A. J. (2011). Perceptions of trends in seychelles artisanal trap fisheries: comparing catch monitoring, underwater visual census and fishers' knowledge. Environ. Conserv. 38, 75-88. doi: 10.1017/ s0376892910000901

Diogo, H., Pereira, J. G., and Schmiing, M. (2017). Experience counts: integrating spearfishers' skills and knowledge in the evaluation of biological and ecological impacts. Fish. Manag. Ecol. 24, 95-102. doi: 10.1111/fme.12206

Froese, R., and Pauly., D. (eds) (2018). FishBase. World Wide Web Electronic Publication. Available at: https://www.fishbase.org (accessed September 9, 2018).

\section{FUNDING}

The authors are grateful to the financial contribution of the Margaret A. Cargill Philanthropies, the David and Lucile Packard Foundation, and the National Science Foundation (award no. 1546590).

\section{ACKNOWLEDGMENTS}

The collection of fisheries data would not have been possible without the kind co-operation of local fishing communities in Sekotong, Lombok, the district government of West Lombok, and the provincial government of West Nusa Tenggara. We are extremely grateful to Tezar Rafandi and Azwar Anas who contributed to the design, coordination, and implementation of field surveys and also Jessica Pingkan who provided the map. We are also grateful to Melati Kaye and two reviewers whose comments helped improve the manuscript.

Gaither, M. R., and Rocha, L. A. (2013). Origins of species richness in the indo-malay-philippine biodiversity hotspot: evidence for the centre of overlap hypothesis. J. Biogeogr. 40, 1638-1648. doi: 10.1111/jbi.12126

Gascuel, D. (2005). The trophic-level based model: a theoretical approach of fishing effects on marine ecosystems. Ecol. Modell. 189, 315-332. doi: 10.1016/ j.ecolmodel.2005.03.019

Gill, D. A., Mascia, M. B., Ahmadia, G. N., Glew, L., Lester, S. E., Barnes, M., et al. (2017). Capacity shortfalls hinder the performance of marine protected areas globally. Nature 543, 665-669. doi: 10.1038/nature21708

Gomes, I., Erzini, K., and McClanahan, T. R. (2014). Trap modification opens new gates to achieve sustainable coral reef fisheries. Aquat. Conserv. 24, 680-695. doi: $10.1002 /$ aqc. 2389

Halim, A. (2002). Adoption of cyanide fishing practice in indonesia. Ocean Coast. Manage. 45, 313-323. doi: 10.1016/s0964-5691(02)00061-3

Harkes, I., and Novaczek, I. (2002). Presence, performance, and institutional resilience of sasi, a traditional management institution in central maluku indonesia. Ocean Coast. Manage. 45, 237-260. doi: 10.1016/s0964-5691(02) 00057-1

Heyman, W. D., and Granados-Dieseldorff, P. (2012). The voice of the fishermen of the Gulf of honduras: improving regional fisheries management through fisher participation. Fish. Res. 125, 129-148. doi: 10.1016/j.fishres.2012.02.016

Hicks, C. C., and McClanahan, T. R. (2012). Assessing gear modifications needed to optimize yields in a heavily exploited, multi-species, seagrass and coral reef fishery. PLoS One 7:e36022. doi: 10.1371/journal.pone.0036022

Hobson, E. S. (1972). Activity of Hawaiian reef fishes during the evening and morning transitions between daylight and darkness. Fish. Bull. 70, 715-740.

Hughes, T. P., Graham, N. A. J., Jackson, J. B. C., Mumby, P. J., and Steneck, R. S. (2010). Rising to the challenge of sustaining coral reef resilience. Trends Ecol. Evol. 25, 633-642. doi: 10.1016/j.tree.2010.07.011

Humphries, A. T., McQuaid, C. D., and McClanahan, T. R. (2015). Contextdependent diversity-effects of seaweed consumption on coral reefs in kenya. PLoS One 10:e0144204. doi: 10.1371/journal.pone.0144204

Irigoien, X., Huisman, J., and Harris, R. P. (2004). Global biodiversity patterns of marine phytoplankton and zooplankton. Nature 429, 863-867. doi: 10.1038/ nature 02593

Johnson, A. E. (2010). Reducing bycatch in coral reef trap fisheries: escape gaps as a step towards sustainability. Mar. Ecol. Prog. Ser. 415, 201-209. doi: 10.3354/ meps08762

Kelly, E. L. A., Eynaud, Y., Williams, I. D., Sparks, R. T., Dailer, M. L., Sandin, S. A., et al. (2017). A budget of algal production and consumption by herbivorous fish in an herbivore fisheries management area, Maui, Hawaii. Ecosphere 8:e01899. doi: $10.1002 /$ ecs 2.1899 
King, J. R., and McFarlane, G. A. (2003). Marine fish life history strategies: applications to fishery management. Fish. Manag. Ecol. 10, 249-264. doi: 10. 1046/j.1365-2400.2003.00359.x

Mangubhai, S., Saleh, M., Muljadi, A., Rhodes, K. L., and Tjandra, K. (2011). Do not stop: the importance of seamless monitoring and enforcement in an Indonesian marine protected area. J. Mar. Biol. 2011:501465.

Marine Conservation Institute (2019). MPAtlas. Seattle, WA: Marine Conservation.

Maypa, A. P., Russ, G. R., Alcala, A. C., and Calumpong, H. P. (2002). Long-term trends in yield and catch rates of the coral reef fishery at apo island, central philippines. Mar. Freshw. Res. 53, 207-213.

McClanahan, T., and Abunge, C. (2018). Demographic variability and scales of agreement and disagreement over resource management restrictions. Ecol. Soc. 23:33.

McClanahan, T. R., and Cinner, J. E. (2008). A framework for adaptive gear and ecosystem-based management in the artisanal coral reef fishery of PApua New Guinea. Aquat. Conserv. 18, 493-507. doi: 10.1002/ aqc. 874

McClanahan, T. R., Graham, N. A., MacNeil, M. A., Muthiga, N. A., Cinner, J. E., Bruggemann, J. H., et al. (2011). Critical thresholds and tangible targets for ecosystem-based management of coral reef fisheries. Proc. Nat. Acad. Sci. U.S.A. 108, 17230-17233. doi: 10.1073/pnas.1106861108

McClanahan, T. R., and Graham, N. A. J. (2015). Marine reserve recovery rates towards a baseline are slower for reef fish community life histories than biomass. Proc. R. Soc. B. U.S.A. 282:20151938. doi: 10.1098/rspb.2015. 1938

McClanahan, T. R., and Humphries, A. T. (2012). Differential and slow life-history responses of fishes to coral reef closures. Mar. Ecol. Prog. Ser. 469, 121-131. doi: $10.3354 /$ meps 10009

McClanahan, T. R., and Mangi, S. C. (2004). Gear-based management of a tropical artisanal fishery based on species selectivity and capture size. Fish. Manag. Ecol. 11, 51-60. doi: 10.1111/j.1365-2400.2004.00358.x

Muawanah, U., Yusuf, G., Adrianto, L., Kalther, J., Pomeroy, R., Abdullah, H., et al. (2018). Review of national laws and regulation in Indonesia in relation to an ecosystem approach to fisheries management. Mar. Policy 91, 150-160. doi: 10.1016/j.marpol.2018.01.027

Nash, K. L., Bijoux, J., Robinson, J., Wilson, S. K., and Graham, N. A. J. (2016). Harnessing fishery-independent indicators to aid management of data-poor fisheries: weighing habitat and fishing effects. Ecosphere 7:e01362. doi: 10.1002/ ecs 2.1362

Ningsih, N. S., Rakhmaputeri, N., and Harto, A. B. (2013). Upwelling variability along the southern coast of bali and in nusa tenggara waters. Ocean Sci. J. 48, 49-57. doi: 10.1007/s12601-013-0004-3

Ogden, J. C., and Buckman, N. S. (1973). Movements, foraging groups, and diurnal migratons of the striped parrotfish scarus croicensis bloch (Scaridae). Ecology 54, 589-596. doi: 10.2307/1935344
Oksanen, J., Kindt, R., and Simpson, G. L. (2017). Vegan3d: Static and Dynamic 3D Plots For The 'Vegan'Package. R Package Version, 1.

Pauly, D., Christensen, V., Dalsgaard, J., Froese, R., and Torres, F. (1998). Fishing down marine food webs. Science 279, 860-863. doi: 10.1126/science.279. 5352.860

Pet-Soede, C., Cesar, H. S. J., and Pet, J. S. (1999). An economic analysis of blast fishing on Indonesian coral reefs. Environ. Conserv. 26, 83-93. doi: 10.1017/ s0376892999000132

Pet-Soede, C., Van Densen, W. L. T., Pet, J. S., and Machiels, M. A. M. (2001). Impact of Indonesian coral reef fisheries on fish community structure and the resultant catch composition. Fish. Res. 51, 35-51. doi: 10.1016/s0165-7836(00) 00236-8

Spalding, M., Spalding, M. D., Ravilious, C., and Green, E. P. (2001). World atlas of Coral Reefs. Berkeley, CA: Univ of California Press.

Taylor, B. M., Houk, P., Russ, G. R., and Choat, J. H. (2014). Life histories predict vulnerability to overexploitation in parrotfishes. Coral Reefs 33, 869-878. doi: 10.1007/s00338-014-1187-5

Teh, L. S. L., Teh, L. C. L., and Sumaila, U. R. (2013). A global estimate of the number of coral reef fishers. PLoS One 8:e65397. doi: 10.1371/journal.pone. 0065397

Walters, C. (2000). Impacts of dispersal, ecological interactions, and fishing effort dynamics on efficacy of marine protected areas: how large should protected areas be? B. Mar. Sci. 66, 745-757.

Walters, C. J. (1986). Adaptive Management of Renewable Resources. London: Macmillan Publishers Ltd.

Watson, M., Righton, D., Austin, T., and Ormond, R. (1996). The effects of fishing on coral reef fish abundance and diversity. J. Mar. Biol. Assoc. U. K. 76, 229-233.

Winemiller, K. O., and Rose, K. A. (1992). Patterns of life-history diversification in North American fishes: implications for population regulation. Can. J. Fish. Aquat. Sci. 49, 2196-2218. doi: 10.1007/s00442-008-1021-2

Yachi, S., and Loreau, M. (1999). Biodiversity and ecosystem productivity in a fluctuating environment: the insurance hypothesis. Proc. Nat. Acad. Sci. 96, 1463-1468. doi: 10.1073/pnas.96.4.1463

Conflict of Interest Statement: The authors declare that the research was conducted in the absence of any commercial or financial relationships that could be construed as a potential conflict of interest.

Copyright (c) 2019 Humphries, Gorospe, Carvalho, Yulianto, Kartawijaya and Campbell. This is an open-access article distributed under the terms of the Creative Commons Attribution License (CC BY). The use, distribution or reproduction in other forums is permitted, provided the original author(s) and the copyright owner(s) are credited and that the original publication in this journal is cited, in accordance with accepted academic practice. No use, distribution or reproduction is permitted which does not comply with these terms. 